\title{
Reminiscing About the Golden Age: An Analysis of Efforts to Revive the Hong Kong Film Industry Through the Lens of Copyright Protection
}

\author{
Yahong Li, Weijie Huang, and Celine Melanie A. Dee
}

\begin{abstract}
The Hong Kong film industry portrayed itself as an international film powerhouse during its golden age. Its light was dimmed on account of the industry's directorcentered production system, prevailing investor pressure, weak infrastructure, political and economic conditions, popularity of foreign films, and rampant piracy. The Hong Kong government established infrastructural solutions and financial remedies to alleviate the industry's plight. Despite those laudable efforts, success has been limited. The key to restoring the film industry to its former glory lies in reforming the traditional Hong Kong copyright framework, including reconstructing the copyright ownership rule, providing breathing space for secondary creation, and decriminalizing individual, noncommercial online sharing.
\end{abstract}

\section{Keywords}

Hong Kong film industry · Copyright reform · Joint authorship · Fair dealing ·

Decriminalization

All online information was last accessed before Aug. 11, 2018

\footnotetext{
Y. Li (ه)

Faculty of Law, The University of Hong Kong, Hong Kong, Hong Kong

Intellectual Property Research Institute, Jinan University, Guangzhou, China

e-mail: yali@hku.hk

W. Huang

Faculty of Law, The University of Hong Kong, Hong Kong, Hong Kong

C. M. A. Dee

Faculty of Law, The University of Hong Kong, Hong Kong, Hong Kong

Legaspi Rosales Law Office, Makati City, Philippines

K.-C. Liu, U. S. Racherla (eds.), Innovation, Economic Development, and Intellectual Property in India and China, ARCIALA Series on Intellectual Assets and Law in Asia, https://doi.org/10.1007/978-981-13-8102-7_7
} 


\section{Introduction}

Once celebrated for its strong cultural identity and dynamism, ${ }^{1}$ the Hong Kong film industry's popularity has declined since its prime in the 1980s and the early 1990s. ${ }^{2}$ The decline was rooted in various political, economic, and social factors. This chapter shall explore the rise and fall of the Hong Kong film industry as well as Hong Kong's efforts to revive its film industry and examine the inadequacies of the traditional Hong Kong copyright framework and the role of copyright law in establishing a better future for the Hong Kong film industry.

\section{$2 \quad$ Hong Kong Film Industry: Growth and Decline}

The Hong Kong film industry finds its roots in Cantonese opera. ${ }^{3}$ The earliest films Stealing a Roasted Duck (1909), Right a Wrong with an Earthenware Dish (1909), and Zhuangzi Tests His Wife (1913) - were based on notable operatic scenes. ${ }^{4}$ Later on, Mandarin features from China influenced the local film industry as a result of the Second World War and Chinese civil war (1945-1949). ${ }^{5}$ Under British colonial rule, Hong Kong was deemed a safe haven of "social order and freedom," " thus attracting capital, talent, and "sophisticated production techniques from the Mainland."7 This led to the development of Mandarin production powerhouses such as the Shaw Brothers and Motion Picture and General Investment Company Limited in Hong Kong. ${ }^{8}$ However, the elaborate production value of Mandarin films proved to be detrimental to smaller local Cantonese films, ${ }^{9}$ resulting in the gradual absence of the latter in the film industry. Despite this, the industry flourished in the $1950 \mathrm{~s}$ and 1960s "with an average production of over 200 films a year."10

The local film industry experienced a shift in the 1970s. After the stoppage of Cantonese film production in $1971-1973,{ }^{11}$ the local film industry not only turned around but achieved international fame with the introduction of Cantonese kung fu

\footnotetext{
${ }^{1}$ Joseph M. Chan, et al., Policies for the Sustainable Development of the Hong Kong Film Industry 9 (Hong Kong Institute of Asia-Pacific Studies, 2010).

${ }^{2} I d$. at 17.

${ }^{3} I d$. at 14 .

${ }^{4}$ Yi Tang, A Bird Known By Its Note: Identity Legitimacy, Network Dynamics, and Actor Performance in the Hong Kong Film Industry, 1970-1997, at 15 (May 2009) (unpublished PhD dissertation, The Hong Kong University of Science and Technology).

${ }^{5}$ Chan, supra note 1 , at 14 .

${ }^{6} I d$.

${ }^{7}$ TANG, supra note 4, at 16. CHAN, supra note 1 , at 15.

${ }^{8} I d$.

${ }^{9}$ Robert Chi, Hong Kong Cinema Before 1980, in A Companion to Chinese Cinema 80 (Yingjin Zhang ed., 2012).

${ }^{10}$ CHAN, supra note 1 , at 15 .

${ }^{11} \mathrm{CHI}$, supra note 9 , at 80 .
} 
films. ${ }^{12}$ The introduction of homegrown talents Bruce Lee, Sammo Hung, and Jackie Chan forever changed the landscape of the industry. ${ }^{13}$ It characterized kung $f u$ as the "signature brand of Hong Kong films." 14 The late 1970s welcomed "New Wave" directors in the likes of Ann Hui, Yim Ho, Tsui Hark, Patrick Tam, Allen Fong, and Alex Cheung. ${ }^{15}$ This new generation of innovative directors "brought about a fresh, more personal approach"16 which vastly improved the quality of domestic films. ${ }^{17}$ It likewise catapulted the industry to international and critical acclaim at film festivals. ${ }^{18}$

The golden age of the industry took place in the 1980s to the early 1990s. During this period, it earned the moniker "Hollywood of the Far East" 19 by producing an average of 400 films a year ${ }^{20}$ and surpassing India as the largest exporter of films in Asia. ${ }^{21}$ It experienced rapid commercial success in both local and overseas markets. ${ }^{22}$ It produced immensely popular movies such as The Shaolin Temple (1982), Project A (1983), Police Story (1985), City on Fire (1987), Rouge (1987), A Chinese Ghost Story (1987), The Greatest Lover (1988), Bullet in the Head (1990), Once Upon in China (1991), Full Contact (1992), and Chungking Express (1994). This period likewise saw the rise of independent production companies and domestically focused cinema circuits ${ }^{23}$ and the emergence of idol-actors who "established a commanding presence at regional box offices." 24

However, the mid-1990s witnessed the drastic decline of the industry. In its efforts to meet the skyrocketing demand of the market, the industry sought to appease its principal investors by inhibiting creativity and resorting to unpolished formulaic productions. ${ }^{25}$ This led to overproduced films devoid of any "sensational impact and visceral stimulation," 26 thus causing dwindling profits and loss of international acclaim at foreign film festivals. ${ }^{27}$

\footnotetext{
${ }^{12}$ CHAN, supra note 1 , at 15 .

${ }^{13} I d$. at 16.

${ }^{14} I d$.

${ }^{15}$ Gina Marchetti, The Hong Kong New Wave, in A Companion to Chinese Cinema 96 (Yingjin Zhang ed., 2012).

${ }^{16} I d$.

${ }^{17}$ CHAN, supra note 1 , at 17 .

${ }^{18}$ e.g. Id.; MARCHETTI, supra note 16, at 97.

${ }^{19}$ Mainland Offers Hong Kong's Film Industry A Chance for a Brighter Future, South CHINA Morning Post, Mar. 18, 2018, available at https://www.scmp.com/comment/insight-opinion/ article/2137677/mainland-offers-hong-kongs-film-industry-chance-brighter

${ }^{20} I d$.

${ }^{21}$ TANG, supra note 4, at 15 .

${ }^{22}$ Chan, supra note 1, at 17. "The annual box office takings of local films soared from HK\$184 million in 1980 to HK\$878 million in 1989 and reached an apex of HK\$1.2 billion in 1992.”.

${ }^{23} I d$.

${ }^{24} I d$.

${ }^{25} I d$. at 18.

${ }^{26} I d$.

${ }^{27}$ Mainland Offers Hong Kong's Film Industry a Chance for a Brighter Future, supra note 19.
} 


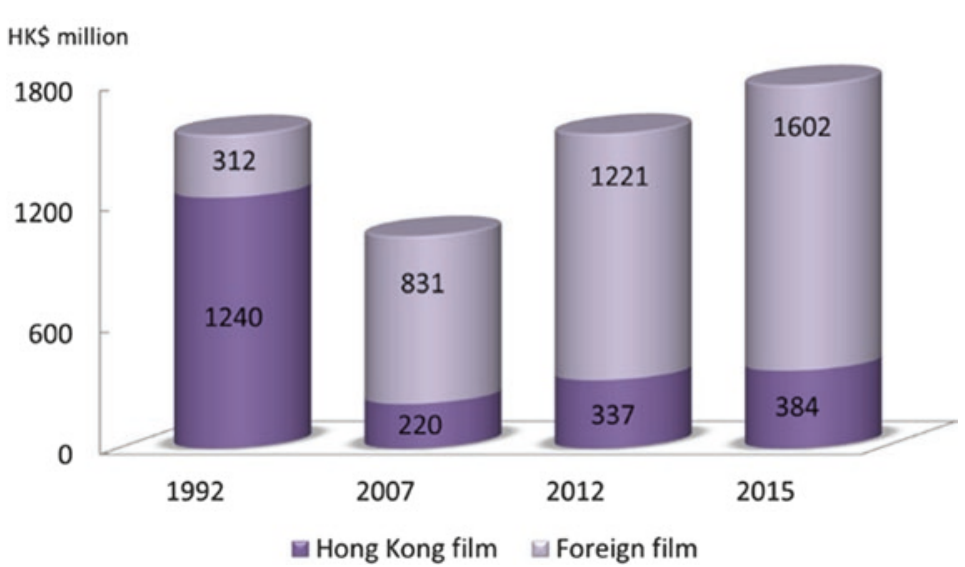

Fig. 1 Box office in Hong Kong by film category. (Data sources: Census and Statistics Department and Commerce and Economic Development Bureau)

The industry has yet to recover, as manifested in the fraction of films produced and the drop in box office receipts. Production output declined to 242 films in 1993, 92 films in 1998, and eventually a record low of 55 films in $2005 .{ }^{28}$ In 1992, the total box office receipts reached HK\$1552 million, with HK\$1240 million contributed by Hong Kong films and HK\$312 million contributed by foreign films. ${ }^{29}$ The revenues declined to $\mathrm{HK} \$ 1051$ million in 2007 , with $\mathrm{HK} \$ 831$ million from foreign films and HK\$220 million from local films. ${ }^{30}$ After a slow recovery, the receipts increased to HK\$1558 million in 2012 and to HK\$1986 million in $2015^{31}$ (Fig. 1). The number gradually increased to HK\$1947 million in 2016 and $\mathrm{HK} \$ 1853$ million in $2017^{32}$ (Fig. 2).

Although the total box office receipts in recent years have been higher than at the industry's peak in 1992, it should be noted that the increase is attributable to receipts of foreign films, and not domestic films. In fact, foreign films contribute nearly $80 \%$ of the total revenue. ${ }^{33}$

The decline in box office receipts is further manifested in the top ten box office results. First Strike, a film produced by Hong Kong-based Golden Harvest movie

\footnotetext{
${ }^{28}$ CHAN, supra note 1 , at 12,14 .

${ }^{29}$ Legislative Council of the Hong Kong Special Administrative Region of the People's Republic of China (LegCo), Challenges of the Film Industry in Hong Kong, available at https://www.legco. gov.hk/research-publications/english/essentials-1516ise13-challenges-of-the-film-industry-inhong-kong.htm.

${ }^{30} I d$.

${ }^{31} I d$.

${ }^{32}$ HKTDC, Film \& Entertainment Industry in Hong Kong (Mar. 15, 2018), available at http:// hong-kong-economy-research.hktdc.com/business-news/article/Hong-Kong-Industry-Profiles/ Film-Entertainment-Industry-in-Hong-Kong/hkip/en/1/1X000000/1X0018PN.htm (last accessed Aug. 8, 2018)

${ }^{33} I d$.
} 


\begin{tabular}{|lcc|}
\hline & $\mathbf{2 0 1 6}$ & $\mathbf{2 0 1 7}$ \\
\hline Number of local films released & 62 & 53 \\
\hline Number of foreign films released & 287 & 278 \\
\hline Total box office receipts (including foreign film) (HK\$ million) & 1,947 & 1,853 \\
\hline
\end{tabular}

Fig. 2 Number of films released and box office receipts. (Source: Hong Kong Box Office Ltd.)

Top 10 box-office hits in Hong Kong

\begin{tabular}{|c|c|c|}
\hline Filim & Studio & $\begin{array}{l}\text { Box office } \\
\text { (taksm) }\end{array}$ \\
\hline First Strike (HK) & Golden Harvest & 157.52 \\
\hline Independence Day (US) & Fox & 49.4 \\
\hline The God of cookery (HW) & CN Entertainment & 40.86 \\
\hline Mission: Impossible (US) & Paramount Pictures & 39.63 \\
\hline Forbidden City Cop (HK) & Samico Films Production & 36.05 \\
\hline The Rock (US) & Hollywood Pictures & 30.56 \\
\hline Twister (US) & Warner Brothers & 28.26 \\
\hline Tristar (HK) & Mandarin Fllms & 25.22 \\
\hline Eraser (US) & Warner Brothers & 24.67 \\
\hline Young and Dangerous (HK) & Golden Harvest & 22.49 \\
\hline
\end{tabular}

\begin{tabular}{ll|l}
\hline 2016 & & \multicolumn{1}{l}{$\begin{array}{l}\text { Box office } \\
\text { (HKSm) }\end{array}$} \\
\hline Filn & Studio & 120.38 \\
\hline Captain America: Civil War (US) & Disney & 66.16 \\
\hline Batman v Superman: Dawn of Justice (US) & Warner Brothers & 63.58 \\
\hline Doctor Strange (US) & Disney & 61.99 \\
\hline Deadpool (US) & Fox & 59.89 \\
\hline The Mermaid (HK/Mainland China) & Edko & 54.79 \\
\hline Zootopia (US) & Disney & 52.13 \\
\hline Fantastic Beasts and Where to Find Them (US) & Warner Brothers & 51.47 \\
\hline Finding Dory (US) & Disney & 51 \\
\hline X-Men: Apocalypse (US) & Fox & 42.74 \\
\hline Rogue One: A Star Wars Story (US) & Disney & \\
\hline
\end{tabular}

Fig. 3 Top 10 box office hits in Hong Kong for 1996 and 2016. (Source: Box Office Mojo, Hong Kong Box Office)

studio, ranked as the highest-grossing film in the domestic market in 1996. In the same year, four other Hong Kong films placed in the top ten box office list. In contrast, only one Hong Kong film (The Mermaid), co-produced with the Mainland, appeared on the 2016 top ten box office list ${ }^{34}$ (Fig. 3).

The Hong Kong film industry's performance at international film festivals was likewise affected. The film industry last submitted entries to the Cannes Film Festival in 2009, to the Berlin International Film Festival in 2008, and to the Venice Film Festival in 2011.35

The decline is attributable to the core model of the Hong Kong film industry and several external factors. The "conservative and opportunistic outlook" 36 of the industry inhibits innovation, thus resulting in overproduction. The lack of infrastructure in both production ${ }^{37}$ and distribution ${ }^{38}$ aspects hinders the development of

\footnotetext{
${ }^{34}$ Celine Ge, It's Fade Out for Hong Kong's Film Industry as China Moves into the Spotlight, South China Morning Post, Jul. 28, 2017, available at http://www.scmp.com/business/article/2104540/its-fade-out-hong-kongs-film-industry-china-moves-spotlight

${ }^{35}$ Hong Kong Free Press, A Glimmer of Hope for Young Filmmakers in Hong Kong's Fading Industry, available at https://www.hongkongfp.com/2017/11/05/ glimmer-hope-young-filmmakers-hong-kongs-fading-industry

${ }^{36} \mathrm{CHAN}$, supra note 1 , at 22 .

${ }^{37} I d$. at 21.

${ }^{38}$ Legislative Council of the Hong Kong Special Administrative Region of the People's RePUblic of China, supra note 29.
} 
the film industry from within. Moreover, its "director-centered production system" 39 causes a drain in technical and artistic talent. ${ }^{40}$ External factors include the political and economic landscape after Hong Kong's handover to China, ${ }^{41}$ strong competition from foreign films, ${ }^{42}$ and rampant piracy. ${ }^{43}$

\subsection{Factors Within the Core Model of the Hong Kong Film Industry}

The core model is characterized by a director-centered production system coupled with investor pressure and a weakening industry infrastructure. These factors resulted in the decrease in the quality of local films.

From previously well-established production houses, the film industry production style is now that of "a cottage industry compris[ing] independent productions known for its filmmakers' frantic work style." 44 The director-centered production system results in a form of "guerrilla filmmaking," in which directors dive into the filmmaking process armed with solely a general plot or storyline. ${ }^{45} \mathrm{He}$ or she improvises throughout the process without any completed scripts. ${ }^{46}$ This process undermines the value and the creative integrity of scriptwriters, ${ }^{47}$ which often results in a

\footnotetext{
${ }^{39}$ David Desser, Triads and Changing Times: The National Allegory of Hong Kong Cinema, 19962000, 26 QRFV 179, 186 (2009) ("The director-centered nature of boutique production"); Mirana M. Szeto \& Yun-chung Chen, To Work or Not to Work: The Dilemma of Hong Kong Film Labor in the Age of Mainlandization, 55 JUMP CUT 1, 3-4, 12 (2013), available at https://www. researchgate.net/profile/Yun_Chung_Chen2/publication/258967573_To_work_or_not_to_work_ the_dilemma_of_Hong_Kong_film_labor_in_the_age_of_mainlandization/links/ 5670d2fe08ae2b1f87acf85a/To-work-or-not-to-work-the-dilemma-of-Hong-Kong-film-labor-in-theage-of-mainlandization.pdf ("The 'director subcontracting' model features a mixed system (19701990), under which "apart from controlling the basic theme and the budget limit, studios remain hands-off, leaving hiring and other decision making to the director." "The flexible independent system (1990s) and the following cross-border production (2000s) were featured by the "directorcentered' model." "Traditionally, the director-centered production system has dominated Hong Kong film production, making collective creativity difficult."); Cindy S. C. Chan, Housekeeper of Hong Kong Cinema: The Role of Producer in the System of Hong Kong Film Industry, 2 WIDE SCREEN 1, 1-2, 7-8 (2010) ("directors routinely started shooting without completed scripts and improvisation on the set was the norm... the directors, instead of the producers, [were] centers of power and creative control... In Hong Kong cinema, the producer, not positioned in [a] vertical relationship with the director, is no auteur or brand name.").

${ }^{40} \mathrm{CHAN}$, supra note 1 , at 21 .

${ }^{41}$ Vivienne Chow, Handover Hangover: Hong Kong's Film Industry Faces an Uncertain Future, VARIETY (May 17, 2017), available at http://variety.com/2017/biz/news/wong-kar-wai1202430867-1202430867

${ }^{42}$ LegCo, supra note 29.

${ }^{43} I d$.

${ }^{44}$ Chan, supra note 39 , at 1 .

${ }^{45} \mathrm{Id}$.

${ }^{46} I d$.

${ }^{47} I d$.
} 
drain of talent. Directors, investors, and even actors participate in "scriptbutchering," 48 often diluting the storyline. Despite the establishment of the Hong Kong Screenwriters' Guild (HKSWG) in 1991, scriptwriters remain weak and unprotected due to the absence of the right to collective bargaining. ${ }^{49}$ Famous actors like Chow Yun Fat have vowed never to return to Hong Kong unless the scripts are better. ${ }^{50}$

Additionally, many filmmakers have succumbed to investors' pressure on decisions over cast and content. ${ }^{51}$ This has proved to be detrimental to the industry, since it has inhibited creativity and resulted in an "over-heated and over-exploited" market. ${ }^{52}$ The pressure to create one blockbuster hit after another has led to lackluster and formulaic films. As a result, the interest of the viewing public has waned, ultimately affecting the demand for Hong Kong films. ${ }^{53}$

The overall poor infrastructure of the industry, particularly in terms of education, production, and distribution, explains the industry's inability to keep up with their foreign counterparts. Hong Kong lacks educational facilities for film staff, ${ }^{54}$ which leads to brain drain. The production infrastructure is marked by a lack of technical facilities for postproduction and distribution. ${ }^{55}$ This has forced the industry to outsource these services to foreign countries, ${ }^{56}$ thus affecting Hong Kong's position as a leading film hub. With regard to distribution, the dearth of local cinemas has also greatly spurred the decline of the industry. Cinemas have dramatically declined in number from 119 in 1993 to 47 in 2015 (Fig. 4), and the number of screens available per 100,000 persons ranks second lowest compared to other major Asian cities (Fig. 5). ${ }^{57}$

\subsection{External Factors}

Apart from issues within the industry, external factors have likewise contributed to the decline. A fundamental reason is the changes arising from the political and economic climate in Hong Kong. Hong Kong's reunification with China in 1997

\footnotetext{
${ }^{48}$ Szeto \& Chen, supra note 39 , at 12.

${ }^{49} I d$. at 5

${ }^{50}$ Hong Kong Movie Industry, Martial Arts Films, Triads and Ghosts, Facts and Details, available at http://factsanddetails.com/china/cat7/sub42/item244.html

${ }^{51}$ CHAN, supra note 1 , at 18 .

${ }^{52} I d$.

${ }^{53} \mathrm{Id}$.

${ }^{54} \mathrm{Ge}$, supra note 34 .

${ }^{55}$ Chan, supra note 1, at 21. LegCo, supra note 29.

${ }^{56}$ CHAN, supra note 1 , at 21 .

${ }^{57}$ Legislative Council Brief on Facilitating Cinema Development, LC Paper No. CB(4)801/16-17(05), available at https://www.legco.gov.hk/yr16-17/english/panels/itb/papers/ itb20170410cb4-801-5-e.pdf (last accessed Jul. 26, 2018).
} 


\begin{tabular}{|c|c|c|c|}
\hline Year & $\begin{array}{c}\text { Number of } \\
\text { cinemas }\end{array}$ & $\begin{array}{c}\text { Number of } \\
\text { screens }\end{array}$ & $\begin{array}{c}\text { Number of } \\
\text { seats }\end{array}$ \\
\hline 1993 & 119 & 188 & 121885 \\
\hline 1994 & 112 & 179 & 125231 \\
\hline 1995 & 104 & 177 & 103504 \\
\hline 1996 & 100 & 181 & 95468 \\
\hline 1997 & 89 & 183 & 77844 \\
\hline 1998 & 77 & 172 & 73407 \\
\hline 1999 & 70 & 185 & 75092 \\
\hline 2000 & 63 & 178 & 69237 \\
\hline 2001 & 62 & 184 & 57372 \\
\hline 2002 & 60 & 179 & 57376 \\
\hline 2003 & 60 & 188 & 52440 \\
\hline 2004 & 57 & 197 & 51340 \\
\hline 2005 & 57 & 207 & 50686 \\
\hline 2006 & 48 & 181 & 42530 \\
\hline 2007 & 48 & 190 & 41332 \\
\hline 2008 & 48 & 192 & 40635 \\
\hline 2009 & 49 & 201 & 40906 \\
\hline 2010 & 49 & 208 & 41157 \\
\hline 2011 & 48 & 204 & 40033 \\
\hline 2012 & 48 & 206 & 39485 \\
\hline 2013 & 45 & 194 & 35937 \\
\hline 2014 & 47 & 208 & 37781 \\
\hline 2015 & 47 & 209 & 37779 \\
\hline
\end{tabular}

Fig. 4 Number of cinemas, screens, and seats in Hong Kong from 1993 to 2015. (Source: Legislative Council Brief Facilitating Cinema Development LC Paper No. CB(4)801/16-17(05))

signified its access to and economic integration with the Mainland market. ${ }^{58}$ However, the onslaught of the 1998 Asian Financial Crisis and the SARS epidemic heavily affected the Hong Kong film industry, causing an economic crisis. ${ }^{59}$

The Mainland offered to boost Hong Kong's economy and strengthen trade relations between the two sides and entered into the Closer Economic Partnership Arrangement (CEPA) in 2003 with Hong Kong. ${ }^{60}$ Under CEPA, Hong Kong and the Mainland developed bilateral rules governing the quota limitations and coproductions of Chinese language motion pictures produced in Hong Kong and the Mainland. ${ }^{61}$

\footnotetext{
${ }^{58} \mathrm{CHI}$, supra note 9 , at 81 .

${ }^{59}$ Chow, supra note 41 .

${ }^{60}$ Mainland and Hong Kong Closer Economic Partnership Arrangement (CEPA), TRADE AND INDUSTRY DEPARTMENT, available at https://www.tid.gov.hk/english/cepa/further_liberal. html

${ }^{61}$ Closer Economic Partnership Agreement, Annex 4, 2. Communication Services.
} 


\begin{tabular}{|l|l|l|l|}
\hline City (Year) & $\begin{array}{l}\text { Number of } \\
\text { screens }\end{array}$ & $\begin{array}{l}\text { Size of } \\
\text { population } \\
\text { (million) }\end{array}$ & $\begin{array}{l}\text { Number of } \\
\text { screens per } \\
\mathbf{1 0 0} \mathbf{0 0 0} \\
\text { persons }\end{array}$ \\
\hline Taipei (2014) & 183 & 2.7 & 6.8 \\
\hline Seoul (2015) & 511 & 10.3 & 5.0 \\
\hline Shenzhen (2014) & 527 & 10.8 & 4.9 \\
\hline Singapore (2015) & 223 & 5.5 & 4.0 \\
\hline Shanghai (2014) & 765 & 24.3 & 3.2 \\
\hline Hong Kong (2015) & $\mathbf{2 0 9}$ & $\mathbf{7 . 3}$ & $\mathbf{2 . 9}$ \\
\hline Tokyo (2015) & 358 & 13.5 & 2.6 \\
\hline
\end{tabular}

Fig. 5 Comparison with some major cities in Asia. (Source: Legislative Council Brief Facilitating Cinema Development LC Paper No. CB(4)801/16-17(05)

Chinese language motion pictures produced in Hong Kong may be imported for distribution in the Mainland on a quota-free basis, after vetting and approval by the relevant Mainland authority. ${ }^{62}$ The benefit does not apply to every Hong Kong film. CEPA defines "Chinese language motion pictures produced in Hong Kong" as those "made by production companies which are set up or established in accordance with the relevant laws of the Hong Kong Special Administrative Region, and which own more than $75 \%$ of the copyright of the motion pictures concerned." 63 It further requires that more than $50 \%$ of the total principal personnel involved in the particular film be Hong Kong residents. ${ }^{64}$

CEPA introduced co-productions between Hong Kong and the Mainland. Co-produced films are considered to be "Mainland motion pictures for the purpose of distribution in the Mainland." 65 No limits are imposed on the "percentage of principal creative personnel from Hong Kong." ${ }^{\text {" How }}$ Hower, it requires that "at least

\section{${ }^{62} I d$. \\ ${ }^{63} I d$. \\ ${ }^{64} I d$.}

2. Chinese language motion pictures produced in Hong Kong refer to those motion pictures made by production companies which are set up or established in accordance with the relevant laws of the Hong Kong Special Administrative Region and which own more than 75\% of the copyright of the motion pictures concerned. Hong Kong residents should constitute more than $50 \%$ of the total principal personnel in the motion pictures concerned.

${ }^{65} \mathrm{Id}$.

3. Motion pictures jointly produced by Hong Kong and the Mainland are treated as Mainland motion pictures for the purpose of distribution in the Mainland. Translated versions of the motion pictures in languages of other Chinese ethnic groups and Chinese dialects, which are based on the Putonghua (Mandarin Chinese) version, are allowed to be distributed in the Mainland.

${ }^{66} I d$. 
one-third of the leading artistes must be from the Mainland." ${ }^{67}$ It also requires that storylines and main characters to be associated with the Mainland. ${ }^{68}$

The Hong Kong film industry believed that CEPA would revitalize the film industry. While CEPA opened the massive Mainland Chinese market to Hong Kongproduced films, increased investments, and generated more jobs, ${ }^{69}$ it also inhibited freedom in the creative process by means of censorship. This translated to revising plot lines and casting actors appealing to the massive Mainland market, regardless of their allure to the local market. ${ }^{70}$ Ultimately, the appeal of the massive Mainland Chinese market drove some Hong Kong filmmakers to forfeit their artistic integrity and creative freedom, to the detriment of the Hong Kong film industry's distinct identity. ${ }^{71}$

The ease of co-production improved the business performance of the Hong Kong film industry. At least $50 \%$ of Hong Kong films were co-productions with filmmakers from the Mainland, and these co-produced films generated more box office receipts, at HK\$234 million. ${ }^{72}$ However, co-production comes with the price of regulation by Mainland film censorship authorities. ${ }^{73}$ This effectively restricted expression and creativity shared through film, diminishing the distinct flavor of locally produced films. Consequently, the interest of local audiences waned due to the absence of cultural relevance and diversity in Hong Kong films. ${ }^{74}$

Another contributing factor is the influx and rising popularity of foreign films from Hollywood, as well as Bollywood and other neighboring countries. On account of Hollywood's "newly aggressive push...in the Asian market,"75 local films had great difficulty in sustaining its market size. ${ }^{76}$ In $2015,80 \%$ of box office receipts were held by foreign films, while only $20 \%$ were held by local films. ${ }^{77}$ This demonstrates consumers' loss of interest in Hong Kong films and increasing appetite for "fast-paced and star-studded Hollywood mega productions."78

The decline is also attributable to piracy. The Hong Kong film industry has been a victim of rampant piracy. Bootlegged VCDs and DVDs collectively contributed to

\footnotetext{
${ }^{67}$ Closer Economic Partnership Agreement, Annex 4, 2. Communication Services. ${ }^{68} I d$.

4. For motion pictures jointly produced by Hong Kong and the Mainland, there is no restriction on the percentage of principal creative personnel from Hong Kong, but at least one-third of the leading artists must be from the Mainland; there is no restriction on where the story takes place, but the plots or the leading characters must be related to the Mainland.

${ }^{69}$ LegCo, supra note 29.

${ }^{70}$ Hong Kong Free Press, supra note 35.

${ }^{71} I d$.

${ }^{72}$ Legislative Council of the Hong Kong Special Administrative Region of the People’s RePublic of China, supra note 29.

${ }^{73}$ Chan, supra note 1 , at $21,22$.

${ }^{74}$ Chow, supra note 41 .

${ }^{75} \mathrm{CHI}$, supra note 9 , at 81 .

${ }^{76} \mathrm{LegCo}$, supra note 29.

${ }^{77} \mathrm{Id}$.

${ }^{78} \mathrm{CHAN}$, supra note 1 , at 22.
} 
a loss of around HK\$300 million to the industry in $1998 .{ }^{79}$ Illegal streaming and peer-to-peer file-sharing platforms, such as BitTorrent, are threats to the film industry. ${ }^{80}$ These internet streaming services resulted in an industry loss of US $\$ 308$ million in 2012. ${ }^{81}$ Rampant piracy has allowed consumers to easily access films, both classic and newly released, at no cost or for a minimal fee. ${ }^{82}$ If eliminated, it will contribute to a $15 \%$ increase in box office receipts. ${ }^{83}$ But if left unchecked, piracy may deter investors, affect the quality of films produced, and cause the ultimate downfall of the Hong Kong film industry.

Overall, the inherent weaknesses of the core model of the film industry and other external factors have gravely crippled the growth of the industry and contributed to the decline in the film industry and the loss of its competitive edge in the global market.

\section{The Road to Revival of the Hong Kong Film Industry}

The Hong Kong government has played a pivotal role in the revival of the Hong Kong film industry. While it is incumbent upon filmmakers to improve the quality of films and upon viewers to support local film culture, the government is in a crucial position to protect and promote the local film industry. For this reason, the government has developed and institutionalized several policies to promote the creative industries which ultimately affect Hong Kong's economy and cultural identity. ${ }^{84}$

\subsection{Hong Kong Film Development Council}

The Hong Kong Film Development Council (FDC) is the government's arm geared toward the promotion and development of the film industry. ${ }^{85}$ Established in 2007, the FDC acts as an advisory body on various policies and strategies put in place for the sustainable development of the film industry. ${ }^{86}$ Through the FDC, industry stakeholders, primarily producers, directors, and film critics collectively collaborate with the government to revive the film industry.

\footnotetext{
${ }^{79}$ LegCo, supra note 29.

${ }^{80}$ Carnegie Mellon University "The Dual Impact of Movie Piracy on Box-Office Revenue: Cannibalization and Promotion", Hong Kong's Piracy Landscape 2018, Feb. 2017 http://hkisa. film/contenthtm1/Information_Material/2018/Hong-Kong-Piracy-Landscape-2018_v4.pdf

${ }^{81}$ Hong Kong Film Industry Furious at YouTube 'Piracy', Asia One, Apr. 25, 2012, available at http://www.asiaone.com/News/Latest\%2BNews/Showbiz/Story/A1Story20120425-342040.html

${ }^{82} I d$.

${ }^{83}$ Hong Kong's Piracy Landscape 2018, supra note 80.

${ }^{84}$ Chan, supra note 1 , at 83 .

${ }^{85}$ Hong Kong Film Development Council, Home Page, available at http://www.fdc.gov.hk/en/ home/index.htm

${ }^{86}$ CHAN, supra note 1 , at 82 .
} 


\subsection{Hong Kong International Film and TV Market and Hong Kong International Film Festival}

In an effort to promote Hong Kong as a global film production and distribution hub, Hong Kong hosts the Hong Kong International Film and TV Market (FILMART) and the Hong Kong International Film Festival (HKIFF), among other industry highlights. Established by the Trade Development Council in 1997, FILMART promotes linkages across various media and platforms for the industry. ${ }^{87}$ This film and TV marketing exhibition is integral to the industry's revival since it advances Hong Kong's status as a core player in the global film industry. ${ }^{88}$ Through FILMART, foreign filmmakers are introduced to Hong Kong as a platform to connect with the global market, including that of the Mainland.

While FILMART focuses on the infrastructure of the film industry, HKIFF dedicates itself to promoting film culture and creativity. Set up in 1977, HKIFF is one of the world's oldest film festivals. ${ }^{89}$ Through its efforts, HKIFF is now "Hong Kong's largest cultural event" and is aimed at promoting "international appreciation of Asian, Hong Kong, and Chinese film culture." ${ }^{90}$ HKIFF is likewise integral to the industry's revival due to its dedication to promoting Hong Kong film culture to the world and recognizing new talents capable of further developing Hong Kong film culture to its fullest.

\subsection{Film Development Fund}

To further the growth of the industry, the government established a Film Development Fund (FDF) as means of financing small-to-medium productions and locally produced Cantonese films for distribution in the Mainland. ${ }^{91}$ Through FDF, the government invested HK\$300 million in 2007 and HK\$200 million in 2015..$^{92}$ Additionally, it infused HK\$20 million in 2016 to aid distribution of Cantonese films in the Mainland. ${ }^{93}$ The Film Production Grant Scheme (2015) and First Feature Film Initiative (2013) were launched to further encourage production of Hong Kong

\footnotetext{
${ }^{87}$ Hong Kong International Film \& TV Market (FILMART), Fair Report, available at http://m. hktdc.com/resources/fair/1819/hkfilmart/s//4129/1527476733800_Fair-Report-FILMART201823May-Eng.pdf

${ }^{88}$ FILMART hosted 8000 global visitors and 800 exhibitors from 35 countries and regions, including over 220 exhibitors from Mainland China in 2017.

${ }^{89}$ Hong Kong International Film Festival Society, About Us, available at http://www.hkiff.org.hk/ society/\#/AboutUs/historyCulture

${ }^{90} I d$.

${ }^{91}$ Hong Kong Film Development Council, Services, available at http://www.fdc.gov.hk/en/services/services $2 . h t m$

${ }^{92} I d$.

${ }^{93} \mathrm{Id}$.
} 
films. ${ }^{94}$ The Film Production Grant Scheme awards cash subsidies to films with a budget of \$ten million or less in order to reduce the risk of film producers and "create nurturing opportunities for practitioners of the film industry." 95 The First Feature Film Initiative offers support to filmmakers without experience in commercial filmmaking by creating jobs for "new on-screen talents and first-timer recruits to film production crews." 96 Through these endeavors, the government provides support to filmmakers and equips them with the financial capacity to produce quality films and tap into the Mainland Chinese and overseas markets.

\subsection{Create Hong Kong (CreateHK) and Hong Kong Arts Development Council}

CreateHK and the Hong Kong Arts Development Council focus on driving the creative and art industries, including film. ${ }^{97}$ CreateHK, a government agency, aims to "build Hong Kong into a regional creative capital" by facilitating creative development. ${ }^{98}$ It assists in film production by coordinating between filmmakers and "over 3,000 organisations on the use of their premises for location filming, and published reference materials on locations for the industry." ${ }^{99}$ Hong Kong Arts Development Council endeavors "to establish Hong Kong as a dynamic and diverse cultural metropolis." ${ }^{100}$ It aids art practitioners, including those in the film industry, by granting fund allocations, promoting art through policy and development, and establishing cultural exchanges. ${ }^{101}$

\subsection{Closer Economic Partnership Agreement}

As previously discussed, the CEPA assists in uplifting the Hong Kong film industry by doing away with quota limitations on the distribution of Hong Kong films in the Mainland and by establishing co-production initiatives between Hong Kong and the rest of China.

\footnotetext{
${ }^{94}$ Legislative Council Panel on Information Technology and Broadcasting, Film Development Fund Review, LC Paper No. CB(4)187/17-18(02), available at https://www.legco. gov.hk/yr17-18/english/panels/itb/papers/itb20171113cb4-187-2-e.pdf

${ }^{95} \mathrm{Id}$.

${ }^{96} I d$.

${ }^{97}$ Hong Kong Free Press, supra note 35.

${ }^{98}$ Create HK, About Us, available at https://www.createhk.gov.hk/en/about.htm\#

${ }^{99}$ Create HK, Services, available at https://www.createhk.gov.hk/en/service_film.htm

${ }^{100}$ Hong Kong Arts Development Council, Cultural Exchange, available at http://www.hkadc.org. $\mathrm{hk} / \mathrm{p}=435$ \&lang=en

${ }^{101} I d$.
} 


\section{$4 \quad$ The Implications of the Hong Kong Copyright Framework on the Film Revival}

While the above efforts aiming at the revival of the film industry are laudable, they fail to address the issue at its core. A common thread among the government's undertakings is the focus on developing infrastructural solutions and improving financial support. However, the means to fully propel the industry to greater heights lies in creating innovative, diverse, and quality Hong Kong films that celebrate the industry's creativity and ingenuity. Despite the government's efforts, the current mechanisms to develop state-of-the-art films continue to face legal barriers in the form of stringent copyright protection.

While movies can be easily pirated as intangible intellectual products, their production and distribution require huge investment. Therefore copyright is paramount in the film industry. According to the statistics published by the Motion Picture Association of America (MPAA) in 2007 (the last year in which the MPAA collected this information), the total average budget for releasing a feature film is US\$106.6 million. ${ }^{102}$ Compared to creators of other categories of cultural products, copyright holders of films have a stronger demand for copyright that allows them to exclusively exploit their films and to recoup investment. Like other jurisdictions, Hong Kong also includes films in copyright law and grants the copyright owners exclusive rights to copy the work; ${ }^{103}$ to issue copies of the work to the public; ${ }^{104}$ to rent copies of the work to the public; ${ }^{105}$ to make available copies of the work to the public $^{106}$ to perform, show, or play the work in public; ${ }^{107}$ and to broadcast the work or include it in a cable program service, ${ }^{108}$ among others. These rights expire at the end of the period of 50 years from the end of the calendar year in which the death occurs of the last to die of the following persons: the principal director, scriptwriter, author of the dialogue, or the composer of music created for and used in the particular film. ${ }^{109}$ However, as we will discuss in the following sections, some Hong Kong copyright rules are inconsistent with the nature of the film and impede the development of Hong Kong's film industry.

\footnotetext{
${ }^{102}$ MPAA, Entertainment Industry Market Statistics (2007) at 7, available at https://wikileaks.org/ sony/docs/03_03/Mktrsch/Market\%20Research/MPAA\%20Reports/2007\%20Market\%20 Statistics.pdf

${ }^{103}$ Copyright Ordinance of Hong Kong (Cap. 528) (2009 amended), section 23.

${ }^{104} I d$. section 24 .

${ }^{105} \mathrm{Id}$. section 25. (Section 25 The rental of copies of any of the following works to the public is an act restricted by the copyright in the work - (a) a computer program, (b) a sound recording, (c) a film, and (d) a literary, dramatic, or musical work included in a sound recording.)

${ }^{106} I d$. section 26.

${ }^{107} I d$. section 27.

${ }^{108} I d$. section 28 .

${ }^{109} \mathrm{Id}$. section 19
} 


\subsection{Co-authorship of Films}

Hong Kong copyright law regards a film as a work jointly authored/owned by the producer and the principal director, ${ }^{110}$ unless the film is made by an employee in the course of his employment, in which case the employer will be the copyright owner but the producer and the principal director remain the co-authors. ${ }^{111}$ Figure 6 shows how this approach differs from many other major film-producing countries.

The major difference between Hong Kong and other jurisdictions is that Hong Kong, which follows the British tradition, allows the director to jointly exploit the film with the producer, while in other countries it is the producer who is solely entitled to exploit the film. Despite the difference of authorship rules, many countries including Italy, France, Germany, China, and Korea grant the right of exploitation to the producer exclusively. Though the USA and Japan subject the film ownership to the work-for-hire doctrine like Hong Kong, they concentrate the exploitation right on a single party, often the producer, when the film is not an employee's work. Under Japanese copyright law, the exploitation right belongs to either the production company in the case of a film made for hire (Art.15) or "the person that makes a creative contribution to the overall shaping of the work through responsibility for its production, direction, staging, filming, art direction, etc." (Art. 16), which most likely refers to the film producer according to the definition of "producer" in other countries (see Fig. 6). In the USA, if a film does not fall into the scope of a work made for hire, the producer will be regarded as the sole author because of the stringent conditions of joint authors. ${ }^{112}$

In Hong Kong, nevertheless, a film is co-owned by the producer and the principal director unless it constitutes an employee's work under a contract of service or of apprenticeship. ${ }^{113}$ However, the film labor system in Hong Kong that changed from contract labor (1930-1970), then a mixed mode of contract and noncontract labor (1970-1990), to flexible, noncontract labor (since 1990) might reduce the number of films that can be considered employee works. ${ }^{114}$ Even if there is a contract, it might be between the director and other employees due to the long-standing

\footnotetext{
${ }^{110} I d$. sections $12(2)$ and 11(2) (b).

${ }^{111}$ Id. section 14. TSE MUI CHUN v. HKSAR - [2003] HKCU 1408 ("As to ownership of copyright, the 'author' of the work is, prima facie, the first owner of the copyright (s.13). But if the 'author' has made the work as an employee in the course of his employment, the employer is the first owner of the copyright (s.14). Note that the employee remains the 'author' but the employer owns the copyright.")

${ }^{112}$ In Casa Duse v. Alex Merkin, the Second Circuit court rejected a film director's claim to be the copyright owner of the film and held the producer to be the sole author ("A co-authorship claimant in the Second Circuit generally must show that each of the putative co-authors (1) made independently copyrightable contributions to the work; and (2) fully intended to be co-authors." 791 F.3d 247, 255 (2d Cir. 2015). Some courts added a "control" criterion, requiring the putative co-authors to exercise control over the work as a whole and serve as its "superintendent" or "mastermind." See Aalmuhammed v. Lee, 202 F.3d 1227, 1234 (9th Cir. 2000).

${ }^{113}$ Copyright Ordinance of Hong Kong (Cap. 528) (2009 amended), section 198.

${ }^{114}$ Szeto \& Chen, supra note 39 , at 3-4.
} 


\begin{tabular}{|c|c|c|c|}
\hline countries & author(s) of a film & $\begin{array}{l}\text { copyright } \\
\text { owner(s) }\end{array}$ & $\begin{array}{l}\text { definition of } \\
\text { the film "producer" }\end{array}$ \\
\hline US & the employer ${ }^{a}$ & the employer & \\
\hline Italy & $\begin{array}{l}\text { the author of the scenario, the composer } \\
\text { of the music and the artistic director }{ }^{\mathrm{b}}\end{array}$ & the producer ${ }^{\mathrm{c}}$ & $\begin{array}{l}\text { the person who has organized the } \\
\text { production of the work }^{\mathrm{d}}\end{array}$ \\
\hline France & $\begin{array}{l}\text { the author of the script, the author of the } \\
\text { adaptation, the author of the dialogue, the } \\
\text { author of the musical compositions, and } \\
\text { the director }\end{array}$ & the producer ${ }^{\mathrm{f}}$ & $\begin{array}{c}\text { The natural or legal person who takes } \\
\text { the initiative and responsibility for } \\
\text { making the work }\end{array}$ \\
\hline Germany & $\begin{array}{l}\text { persons who have jointly created a work } \\
\text { without it being possible to separately } \\
\text { exploit their individual shares in the work }\end{array}$ & the producer ${ }^{\mathrm{i}}$ & \\
\hline Japan & $\begin{array}{l}\text { the person that makes a creative } \\
\text { contribution to the overall shaping of the } \\
\text { work through responsibility for its } \\
\text { production, direction, staging, filming, art } \\
\text { direction, etc., other than the author of a } \\
\text { novel, scenario, music, or other work that } \\
\text { is adapted into or reproduced in the } \\
\text { cinematographic work, unless it is a } \\
\text { made-for-hire work }\end{array}$ & $\begin{array}{l}\text { the same as } \\
\text { the author }\end{array}$ & \\
\hline China & the producer ${ }^{1}$ & the producer & \\
\hline Korea & the producer ${ }^{\mathrm{m}}$ & the producer & $\begin{array}{l}\text { the person who plans and takes } \\
\text { responsibility for the production of a } \\
\text { cinematographic work }\end{array}$ \\
\hline $\begin{array}{c}\text { Hong Kong } \\
\text { /UK }\end{array}$ & the producer and the principal director ${ }^{\circ}$ & $\begin{array}{l}\text { the producer and } \\
\text { the principal } \\
\text { director, unless it } \\
\text { is an employee's } \\
\text { work }^{\mathrm{p}}\end{array}$ & $\begin{array}{l}\text { the person by whom the arrangements } \\
\text { necessary for the making of the film } \\
\text { are undertaken }{ }^{\mathrm{q}}\end{array}$ \\
\hline
\end{tabular}

Fig. 6 Comparison of the rules of authorship and ownership in a film

a17 USC $\S 101$ "Motion picture" was introduced to US copyright law in 1912 as a category of made-for-hire work

${ }^{b}$ Law for the Protection of Copyright and Neighboring Rights in Italy (2010 amended), article 44 'Id. article 46

dId. article 45

'Intellectual Property Code of France (2003 amended), article L113-7

fId. article L132-24

IId. article L132-23

${ }^{\mathrm{h}}$ Act on Copyright and Related Rights of Germany (2017 amended), article 8

id. articles 89 and 94

${ }^{j}$ Copyright Law of Japan (2009 amended), article 15(1) and article 16

${ }^{k}$ Copyright Law of Japan (2009 amended), article 15(1) and article 16

'Copyright Law of the People's Republic of China (2010 amended), article 15

${ }^{\mathrm{m} C}$ Copyright Act of the Republic of Korea (2009 amended), articles 75 (1) and 76

"Id. article 2

${ }^{\circ}$ Copyright Ordinance of Hong Kong (Cap. 528) (2009 amended), section 12(2) and section 11(2) (b). Copyright, Designs and Patents Act 1988 of UK (Chapter 48) (2017 amended), section 9(2) (ab) and section 10(1A)

${ }^{\mathrm{P} C o p y r i g h t ~ O r d i n a n c e ~ o f ~ H o n g ~ K o n g ~(C a p . ~ 528) ~(2009 ~ a m e n d e d), ~ s e c t i o n ~ 14 . ~ C o p y r i g h t, ~ D e s i g n s ~}$ and Patents Act 1988 of UK (Chapter 48) (2017 amended), section 11(2)

${ }^{q}$ Copyright Ordinance of Hong Kong (Cap. 528) (2009 amended), section 198. Copyright, Designs and Patents Act 1988 of UK (Chapter 48) (2017 amended), section 178 
director-centered production system, ${ }^{115}$ whereas the judges have tended to hold films to be co-owned by the producer and director rather than being an employee's work owned by the director. ${ }^{116}$ However, joint ownership is prone to conflicts, including conflicts between the interests of the producer and principal director and the conflicts of applicable laws when the joint owners are from different jurisdictions such as in the case of co-production.

Further, joint ownership adds to the difficulties and costs of identifying copyright owners. Neither "principal director" nor "director" is defined under Hong Kong law. ${ }^{117}$ Departing from the definition of "producer" in other countries normally featured by responsibility (Fig. 6), the Hong Kong counterpart, defined as "the person by whom the arrangements necessary for the making of the film are undertaken," 118 is confusing in regard of the "necessity" of the arrangements. For example, in Century Communications v Mayfair Entertainment, ${ }^{119}$ a film made in China (under the control of the plaintiff) was held to be produced by a Hong Kong company (the defendant). Despite the plaintiff's arrangements such as engaging directors and employing actors, the court ruled in favor of the defendant, reasoning that it was the defendant who initiated the filmmaking and paid for it. ${ }^{120}$ In Beggars Banquet $v$ Carlton Television, the court decided that the person directly responsible for finance, rather than the person who paid the money, should be the producer. ${ }^{121}$ In $A \& M$ Records Ltd. v. Video Collection International Ltd., the person who initiated the process and contracted conductors, rather than the conductor who booked and paid for the orchestra and the studio, was considered the producer who makes necessary arrangements. ${ }^{122}$

As a special feature of Hong Kong film, the co-authorship, or the co-ownership enjoyed by the producer and director, suited the "director-centered production system" ${ }^{23}$ very well. The advantage of this system was especially evident in the

\footnotetext{
${ }^{115} I d$. at 4 .

${ }^{116}$ Century Communications v Mayfair Entertainment, [1993] EMLR 335. Although this is a British case, the Hong Kong Copyright Ordinance inherits it and adopts the same copyright rule as Britain.

${ }^{117}$ Though Laddie, Prescott, and Vitoria's Fourth Edition indicates that the principal director is "likely to be the person who has creative control of the making of the film" (para 7.41), it is not a Hong Kong authority.

${ }^{118}$ Copyright Ordinance of Hong Kong (Cap. 528) (2009 amended), section 198.

${ }^{119}$ [1993] EMLR 335. Although this is a British case, the Hong Kong Copyright Ordinance inherits the British tradition and also regards a film as a work of joint authorship.

${ }^{120}$ [1993] EMLR 335.

${ }^{121}$ [1993] EMLR 349.

${ }^{122}$ [1995] EMLR 251. Although this is a case of sound recording copyright, the definition of "producer" applies to both sound recordings and films. Cap 528, § 198.

${ }^{123}$ See supra note 39 .
} 
kung fu genre ${ }^{124}$ and brought Hong Kong's film industry to the golden age from the 1980 s to the early 1990s. However, a wide range of films that spawned later, from adventure films and comedies to dramas and musical films, rely heavily on other talents such as scripters and composers, not only directors. ${ }^{125}$ The privilege of directors may hold up the collaborative filmmaking process and may even drive homegrown talent to seek greener pastures in the film industries of foreign countries. ${ }^{126}$ Perhaps concentrating the exploitation right on a single party with a clear definition of ownership can reduce the cost of negotiation, clarify the scope of film copyright, and facilitate co-production with other regions. In fact, the Law Reform Commission in Hong Kong suggested that the producer should become the sole copyright owner of a film, although the proposal failed to be finally adopted. ${ }^{127}$

\subsection{Unclear Scope of "Copy" and Insufficient Protection for Secondary Creation}

Section 7(4) of Hong Kong Copyright Ordinance explicitly claims that "copyright does not subsist in a film which is, or to the extent that it is, a copy taken from a previous film." 128 Undoubtedly, copyright "does not subsist in a copy taken from a previous film" because originality is the basic requirement to attract copyright protection. Disputes arise because of the ambiguity contained in the provision "copyright does not subsist in a film which to the extent is a copy taken from a previous film." Specifically, "to the extent is a copy" is a gray area between a verbatim, exact copy without any change to the previous film and a derivative, new film which gains copyright protection because of its originality and substantial difference from other works. Hong Kong Copyright Ordinance acknowledges that both copying a whole work and copying any substantial part of the work constitute a copy ${ }^{129}$ but fails to

\footnotetext{
${ }^{124}$ Many kung fu directors are turned from martial arts actors or instructors and play significant roles in arranging the entire filmmaking process. Sek Kei, Rolanda Chu, and Grant Foerster, A Brief Historical Tour of the Hong Kong Martial Arts Film, January 1, 2001, Bright Lights https:// brightlightsfilm.com/wp-content/cache/all/brief-historical-tour-hong-kong-martial-arts-film/\#. W3rD4egzY2x ("Most professional directors were not actually familiar with martial arts techniques, and ... required the help of martial arts directors such as Sammo Hung and Han Ying Chieh. With the emphasis on martial arts techniques as the new backbone of the genre, contributions from actual martial artists became increasingly significant.”).

${ }^{125}$ F. Jay Dougherty, Not a Spike Lee Joint--Issues in the Authorship of Motion Pictures under the US Copyright Law, 49 UCLA L REV 225, 285 (2001).

${ }^{126}$ CHAN, supra note 1 , at 21 .

${ }^{127}$ The Law Reform Commission of Hong Kong Report: Reform of the Law Relating to Copyright (Topic 22), p 22, 63 https://www.hkreform.gov.hk/en/docs/rcopyright-e.pdf (“3.4 The 'maker' of a cinematography film is the owner of the copyright (section 13(4)), in this case defined as "the person by whom the arrangements necessary for the making of the film are undertaken (section $13(10) "$... "7.10 The employee has no right to be identified as author. A film director is treated in a similar fashion if he is an employee.").

${ }^{128}$ Copyright Ordinance of Hong Kong (Cap. 528) (2009 amended), section 7(4).

${ }^{129} I d$. section 22 (3)(a).
} 
define "substantiality." Hong Kong case law, although it lacks clear guidance regarding the boundary of substantial taking in the field of films, ${ }^{130}$ indicates that even a small amount of taking, such as taking a short musical snippet from another's song, ${ }^{131}$ reproducing a smaller version of the front page of a rival newspaper, ${ }^{132}$ and copying a small part of a questionnaire, ${ }^{133}$ will fall into the scope of copyright infringement.

Following this reasoning, a film created from several clips of one or more previously existing films, a remixed film, a colorized or extended version of a film, a director's cut (namely, an edited version of a film that is supposed to represent the director's own approved edit ${ }^{134}$ ), or a digitally enhanced or restored print will likely be classified as "a copy" in which copyright does not subsist. ${ }^{135}$ The indiscriminate, bald opposition against copying crucially misunderstands the nature of films. As a transnational cultural product, ${ }^{136}$ a film appeals to its audience by providing a novel experience of a new culture. However, the new product and experience should not be too far away from knowledge that the audience already has. This is a sophisticated balance between similarities and differences ${ }^{137}$ between unknown cultural secrets and easy accessibility. ${ }^{138}$ As Abraham Drassinower notes, culture is copying, and copying per se is not wrong. ${ }^{139}$ It is copying that makes the connection between similarities and differences, which explains the continual popularity of movie series such as the Harry Potter series and the Marvel series.

Some may argue that this provision merely prohibits the copying of expression, while the idea is still in the public domain, freely available for everyone. But the boundary between idea and expression is as vague as the boundary between copying and recreation. For instance, Steven Chow, the director for Shaolin Soccer, might exclude others from making a similar kung fu soccer film by arguing that he created his own original kung fu expressions based on the idea of soccer playing, but it is also reasonable to regard soccer as an expression (action and speed) and kung fu as an idea (power, strength of will, hard work, and dignity). ${ }^{140}$ The real cultural

\footnotetext{
${ }^{130}$ Doreen Weisenhaus, Hong Kong Media Law: A Guide for Journalists and Media Professionals 235 (Hong Kong University Press, 2004).

${ }^{131}$ Ladbroke (Football) v William Hill (Football) [1964] 1 WLR 272.

${ }^{132}$ Group Ltd v Apple Daily Ltd [1999] 4 HKC 131.

${ }^{133}$ Lam Tai Hing v Koo Chih Ling, Linda [1993] 2 HKC 1.

${ }^{134}$ Wikipedia's interpretation of "Director's Cuts", available at https://en.wikipedia.org/wiki/ Director\%27s_cut

${ }^{135}$ Pascal Kamina, Film Copyright in the European Union 106 (Cambridge University Press, 2016).

${ }^{136}$ Laikwan Pang, Cultural Control and Globalization in Asia: Copyright, Piracy, and Cinema 10 (New York: Routledge, 2006).

${ }^{137} I d$. at 6 .

${ }^{138} \mathrm{Id}$, at 55 .

${ }^{139}$ Abraham Drassinower, What's Wrong with Copying? 1, 9 (Harvard University Press, 2015).

${ }^{140}$ PANG, supra note 136 , at 53 .
} 
copying practice is more complex than what is written in copyright law. ${ }^{141}$ Actually, as Laikwan Pang noted, the artificial dichotomy of idea/expression is designed more for satisfying capitalist interests than for promoting creativity and culture. ${ }^{142}$ It enables Hollywood to rapidly and effectively appropriate other cinematic traditions, to remake films, and then to exclude others from exploiting the same stories. ${ }^{143}$ But for the domestic industry, the blurred boundary between idea and expression, along with the difficulty in distinguishing copying and recreation, will obstruct the production of movies of the same style and hinder Hong Kong films from forming a collective identity. ${ }^{144}$

The prohibitive effect of copyright law is even exacerbated by the lack of copyright exceptions providing some breathing space for secondary film creation. ${ }^{145}$ This is extremely crucial in the Internet age, where various kinds of user-friendly tools empower a large number of untrained ordinary people to engage in filmmaking themselves such as DIY cinema, newsreel films, ${ }^{146}$ short films, ${ }^{147}$ and microfilm. ${ }^{148}$ As section 2 of the chapter shows, Hong Kong's government has made great efforts in promoting filmmaking, both professional and amateur, whereas legal support is still to be desired. Encouraged by the open-ended fair use doctrine in the USA, ${ }^{149}$ the Australian initiative incorporating parody and satire into fair dealing exception, the Canadian exception for noncommercial user-generated content, and the UK fair dealing exception for parody, caricature, and pastiche, ${ }^{150}$ Hong Kong's Copyright (Amendment) Bill 2014 introduced a safety valve for "parody, satire, caricature, or pastiche." ${ }^{151}$ Nevertheless, the Hong Kong bill ultimately failed to be adopted into law, mainly because copyright owners insisted on the existing copyright ordinance

\footnotetext{
${ }^{141} I d$.

${ }^{142} I d$. at 51 .

${ }^{143} I d$. at 70 .

${ }^{144} I d$. at 98 .

${ }^{145}$ Joseph P. Liu, Copyright and Breathing Space, 30 Colum. J.L. \& ARTs 429, 429 (2006).

${ }^{146}$ Newsreels were short films shown in movie theaters, generally along with cartoons and feature films. Princeton University Library, https://libguides.princeton.edu/c.php?g=84226\&p=540944

${ }^{147}$ According to the Academy of Motion Picture Arts and Sciences, "a short film is an original motion picture that has a running time of 40 min or less, including all credits" https://www.oscars. org/sites/oscars/files/88aa_rule19_short.pdf. Many websites such as YouTube, Snoovies, CinemaClubby, and Vimeo encourage the creation and distribution of user-created short films.

${ }^{148}$ Microfilm, or microcinema, "refers to a gathering of video and filmmakers, music video producers, amateurs, and semiprofessionals, to publicly project, exhibit, and share their creations among groups of friends and neighbors." Jesse Drew, A Social History of Contemporary Democratic Media 45 (London: Routledge, 2013).

${ }^{149}$ Though the US fair use doctrine does not explicitly list parody as an exception, many case laws have regarded parody as fair use. e.g., Campbell v. Acuff-Rose Music, 510 U.S. 569 (1994), Leibovitz v. Paramount Pictures Corp., 137 F.3d 109 (2d Cir. 1998), Suntrust v. Houghton Mifflin Co., 268 F.3d 1257 (11th Cir. 2001), Mattel Inc., v. Walking Mountain Productions, 353 F.3d 792 (9th Cir. 2003).

${ }^{150}$ Legislative Council Brief of Copyright (Amendment) Bill 2014, at 7-9.

${ }^{151}$ Copyright (Amendment) Bill 2014 of Hong Kong, section 39A.
} 
with no amendment at all and users feared that the government might imprison users who engage in secondary creation other than "parody, satire, caricature, or pastiche." 152

In the past, most secondary creations were private and thus remained unregulated by the government or tolerated by copyright holders. However, due to the participatory and hyperconnected web, ${ }^{153}$ a transformation which Henry Jenkins called "from home movies to public movies" occurs, and a much wider audience gets involved. ${ }^{154}$ The popularity of homemade movies and the big business behind them inevitably move those secondary creations, which were originally in the gray area, to the front, directly facing the challenge of copyright law. If the law insists on illegalizing or even criminalizing these uses, these new modes of filmmaking will be stifled, and the potential of mass creativity unleashed by the Internet age will be inhibited.

\subsection{Criminal Liability for Copyright Infringement}

Hong Kong copyright law imposes harsh penalties, both civil and criminal, on copyright infringement. As the Court of Appeal of Hong Kong has noted, copyright infringement "is not simply a matter of the private interests of the copyright owners" but "a matter of public interest to Hong Kong generally"; hence "the remedies available for infringement of copyright can be extensive." 155 Civil remedies include compensation in the form of damages, injunction, an account of profits, and an order for delivery up. ${ }^{156}$ Criminal penalties include a fine of up to $\mathrm{HK} \$ 50,000$ for each infringing copy and imprisonment of a maximum of 4 years, ${ }^{157}$ which specifically pertain to end users who possess, copy, and distribute an infringing copy of certain types of work for the purpose of trade or business. ${ }^{158}$ However, if the distribution is to such an extent as to prejudice the copyright owner, the distributor will be subject to criminal sanction irrespective of the types of copyright works and the

${ }^{152}$ Peter K. Yu, The Quest For A User-Friendly Copyright Regime In Hong Kong, 32 AM. U. INT'L L. REV. 284, 288 (2016).

${ }^{153}$ Nicholas A Christakis and James H Fowler, Connected: The Surprising Power of Our Social Networks and How They Shape Our Lives 10 (Little, Brown 2009).

${ }^{154}$ David Thorburn \& Henry Jenkins, Rethinking Media Change: The Aesthetics of Transition 309 (Cambridge: The Mit Press, 2004).

${ }^{155}$ Commissioner of Customs and Excise v. Golden Science Technology Ltd, [1999] 4 HKC 169.

${ }^{156}$ Copyright Ordinance of Hong Kong (Cap. 528) (2009 amended), sections 107-109.

${ }^{157}$ Copyright Ordinance of Hong Kong (Cap. 528) (2009 amended), section 119.

${ }^{158}$ End users engaging in the following two types of copyright infringement will attract criminal liability: (i) unauthorized possession of an infringing copy of copyrighted software, movies, television dramas, and musical (sound or visual) recordings for use in business and (ii) unauthorized copying and distribution of an infringing copy, either an electronic or hard copy, of books, newspapers, magazines, and periodicals for use in trade or business. Hong Kong's Amended Copyright Law: Guidance Note on Prevention of End-User Piracy in Business at 2, available https://www.ipd. gov.hk/eng/intellectual_property/copyright/booklet_piracy_in_business_e.pdf 
purpose of distribution. ${ }^{159}$ These liability rules are not simply written but also efficiently enforced. ${ }^{160}$

The world's first case imposing criminal liability upon an individual using BitTorrent for P2P sharing, Chan Nai Ming v HKSAR, ${ }^{161}$ occurred in Hong Kong. ${ }^{162}$ The key issue was whether uploading files constitutes "distribution." 163 The defendant used the legal loophole that "distribution" is nowhere defined in Hong Kong Copyright Ordinance, claiming that the prosecutor cannot prove that Chan's act of uploading violates the right of distribution because there is no delivery of "physical copies." 164 As a response, Justice Beeton extended "distribution" to "digital dissemination," reasoning that " distribution' in its ordinary meaning, is clearly capable of encompassing a process in which the distributor first takes necessary steps to make the item available and the recipient then takes steps of his own to obtain it." Through a liberal interpretation of the Copyright Ordinance, the Court decisively gave the law proper effect in combating piracy. The criminalization of copyright infringement has indeed become an evident character of Hong Kong copyright law. From a case search in Lexis $\mathrm{HK},{ }^{165}$ we found 42 cases addressing film copyright, among which 27 cases involved criminal liability of copyright infringement. ${ }^{166}$

However, rigorous liability and harsh punishment from copyright law have failed to fulfill the goal of eliminating piracy. According to a report from Carnegie Mellon University, in 201765.9 million BitTorrent movie and TV programs were

\footnotetext{
${ }^{159} I d$.

${ }^{160}$ e.g., HKSAR v Elegant Technology Ltd, [2004] 3 HKC 37; HKSAR v Ho Hon Chung Danel \& ORS, [2004] 3 HKC 304; HKSAR v Re Affluence Pictures Ltd, [2008] HKCU 1807; HKSAR v SZE Chak Ming \& ANOR, [2006] HKCU 724; HKSAR v Mega Laser Products (HK) Ltd \& ORS, [1999] 3 HKC 161.

${ }^{161}$ CHAN NAI MING v HKSAR, [2007] 3 HKC 255.

${ }^{162}$ Michael Filby, Big Crook in Little China: The Ramifications of the Hong Kong BitTorrent Case on the Criminal Test of Prejudicial Effect, 21 Int Rev. Law Comput Tech 275, 278 (2007).

${ }^{163}$ HKSAR v Chan Nai Ming [2005] 4 HKLRD 142.

${ }^{164}$ One of the key defenses was that although the Copyright Ordinance stipulates the civil remedies for "making available of copies to the public" in section 26, for imposing criminal liability, the prosecutor should demonstrate that Chan's act of uploading violates the right of distribution, but "distribution" is nowhere defined in the Ordinance. HKSAR v Chan Nai Ming [2005] 4 HKLRD 142

${ }^{165}$ By using the term "All Hong Kong Cases" as the source, "atleast3(film) AND atleast3(copyright)," "atleast3(motion picture) AND atleast3(copyright)," and "atleast3(movie)AND atleast3(copyright)" as the search terms respectively three times. "Atleast" is used to search for terms occurring at least so many times in a document. For example, atleast3(film) requires the term "film" to appear in the document at least 3 times. "And" can be used to search for terms located in the same document. For example, "atleast3(film) AND atleast3(copyright)" requires both terms "film" and "copyright" to appear in the document at least 3 times. We used 3 to preliminarily screen cases irrelevant to film copyright.

${ }^{166}$ We obtained 76 cases with "atleast3(film) AND atleast3(copyright)" as the search term, 12 cases with "atleast3(movie) AND atleast3(copyright)" as the search term, and 5 cases with "atleast3(motion picture) AND atleast3(copyright)" as the search term. After reading the decisions of each ease, excluding duplicating cases, we ultimately obtained 42 relevant cases. http://www. lexisnexis.com.eproxy.lib.hku.hk/ap/ui/go.aspx/hk/lexis/default/api?ipf=t
} 
downloaded, and a loss of HK\$ 286 million was caused to the Hong Kong box office. ${ }^{167}$ Online piracy of films, video clips, music, and animation is leading to a monthly loss of around HK\$120 million to Hong Kong's creative industries. ${ }^{168}$ Penalties alone are insufficient to deter infringement. The deterrent effects of law depend upon two factors, the probability of being caught and the severity of the punishment. ${ }^{169}$ For most private pirates, the probability of being caught is very low because of the high cost of tracing anonymous pirates, each of whom merely causes minimal loss to the copyright owners. As Peter Yu concluded, criminal penalties under Hong Kong copyright law are "likely to be selectively enforced and therefore highly unfair."'170

The governance of piracy should take an approach integrating the reasons why piracy originated and became popular. Piracy promises consumers easy access to films, both classic and newly released, at no cost or for a minimal fee. ${ }^{171}$ However, audiences have to bear a long lag time between a film's first release in theater and the release of pirated DVDs or the release of pirated films online and to endure the low quality of early-release pirated films such as camcorder captures in cinemas. ${ }^{172}$ By contrast, authorized films promise the latest movies immediately upon cinema release, an awesome big-screen experience, and sometimes even film appreciation activities such as a face-to-face encounter with film directors or actors and postscreening sharing sessions. ${ }^{173}$ But consumers need to pay for the movie ticket.

Assuming the price of a movie ticket remains the same, the best way to solve piracy is to improve the movie theater experience. A film is not only a commodity but a complex system of representation and cultural experience, ${ }^{174}$ and this experience highly relies on the equipment. The experience of watching movies with fuzzy images on a small and cheap VCD set or in a small PC screen at home can never compare with the experience of watching HD movies in a cinema with state-of-theart facilities. ${ }^{175}$ This is why Gabe Newell, the CEO and cofounder of Valve, pointed out that "piracy is a service problem." ${ }^{176}$ Hong Kong's government seems to recognize the cinema experience approach to combating piracy, making it a policy to

\footnotetext{
${ }^{167}$ Hong Kong's Piracy Landscape 2018, supra note 80.

${ }^{168}$ Alice Shen, Online piracy clampdown in Hong Kong deprives errant websites of HK\$6.5 million in monthly ad revenue, SOUTH CHINA MoRnING Post, Mar. 22, 2018, available at https://www.scmp.com/ news/hong-kong/law-crime/article/2138287/online-piracy-clampdown-hong-kong-deprives-errant-websites ${ }^{169}$ Robert Cooter \& Thomas Ulen, LaW and Economics 4-5 (Boston: Pearson, 6th ed., 2010).

${ }^{170}$ Peter K. Yu, Digital Copyright Reform and Legal Transplants in Hong Kong, 48 U. Louisville L. Rev. 693, 704 (2010).

171 "Hong Kong Film Industry Furious at YouTube 'Piracy'," supra note 81.

${ }^{172}$ William Fisher, Promise to Keep: Technology, LaW and the Future of Entertainment 68 (Stanford University Press, 2004).

${ }^{173}$ Legislative Council Brief on Facilitating Cinema Development, LC Paper No. CB(4)801/16-17(05), supra note 57, at 4 .

${ }^{174}$ PANG, supra note 136 , at 64 .

${ }^{175} \mathrm{Id}$. at 91 .

${ }^{176}$ Greg Tito, Valve's Gabe Newell Says Piracy Is a Service Problem, THE EscaPIST (Nov. 28, 2011) available at http://www.escapistmagazine.com/news/view/114391-Valves-Gabe-Newell-Says-Piracy-Is-a-Service-Problem
} 
facilitate the construction of movie sets in commercial complexes, such as incorporating a cinema requirement in land leases to give a hardware boost. ${ }^{177}$

Criminal penalties not only have failed to combat piracy but also have become barriers for individual, noncommercial file-sharing activities which might be considered to occur "to such an extent as to affect prejudicially the copyright owner" due to the hyperconnected Internet and the unprecedented scope of distribution. Criminalizing file sharing violates the long-standing principle that punishment should fit the crime ${ }^{178}$ and will gradually breed disrespect for and distrust of the legal system. This partly explains the public's fear about the government's prosecution against users who use online-copyrighted material for secondary creation or mocking politicians ${ }^{179}$ even though the Copyright (Amendment) 2014 Bill clarified the threshold of criminal liability regarding the existing prejudicial distribution offenses. ${ }^{180}$ Imposing criminal penalties upon file-sharing activities which are common or even popular with the general public also has huge implications for government finance, prison management, and jurisdictional issues. ${ }^{181}$ We therefore concur with many scholars and are of the opinion ${ }^{182}$ that copyright protection for individual, private, and noncommercial online copying and distribution should be decriminalized. Without such a move, the revival of Hong Kong's film industry will remain a fiction.

\section{Conclusion}

From its humble beginnings, the Hong Kong film industry catapulted itself to an international film powerhouse status. Through the years, it introduced the world to kung fu films of Bruce Lee, Jackie Chan, and the like. However, a variety of factors ranging from the industry's director-centered production system, prevailing investor pressure, and weak infrastructure to political and economic conditions, popularity of foreign films, and rampant piracy all led to its decline. In an effort to revive the industry, the government established infrastructural and financial reforms by means

\footnotetext{
${ }^{177}$ LegCo, supra note 29.

${ }^{178} \mathrm{Yu}$, supra note 187 , at 704.

${ }^{179}$ Stuart Lau, Five reasons the Hong Kong copyright bill failed, South CHINA MoRNING Post, Mar. 4, 2016, https://www.scmp.com/news/hong-kong/politics/article/1920569/five-reasons-hong-kong-copyright-bill-failed ${ }^{180}$ Legislative Council Brief of Copyright (Amendment) Bill 2014 of Hong Kong, supra note 150, para.9-10, at 6-7.

${ }^{181}$ CoOTer \& Ulen, supra note 169, at 489-491.

${ }^{182}$ Yu, supra note 169, at 217. Yu, supra note 185, at 701. Jojo Y.C. Mo, The Copyright (Amendment) Bill 2014 in Hong Kong: A Blessing or a Curse? 38 Stat. L. R. 211, 213 (2017). Christophe Geiger, Challenges for the Enforcement of Copyright in the Online World: Time for a New Approach in Research Handbook on the Cross-Border Enforcement of Intellectual Property 706, 718 (Paul Torremans ed., Edward Elgar Pub., 2014).
} 
of exhibitions, film festivals, and co-productions with the Mainland. While laudable, these efforts remain insufficient to fully propel the Hong Kong film industry to greater heights.

Restoring Hong Kong to its status as the "Hollywood of the Far East" would require the production of innovative, creative, and quality Hong Kong films. However, the traditional Hong Kong copyright framework poses a legal barrier to further innovation and development. The revival of the film industry relies on breaking down these barriers through copyright reform, such as concentrating copyright ownership to a single party who is clearly defined, making copyright exceptions for secondary creation and decriminalizing individual, noncommercial online sharing activities.

\section{References}

\section{Codes and Statutes}

Act on Copyright and Related Rights of Germany (2017 amended).

Closer Economic Partnership Agreement (CEPA).

Copyright Act of the Republic of Korea (2009 amended).

Copyright, Designs and Patents Act 1988 of UK (Chapter 48) (2017 amended).

Copyright Law of Japan (2009 amended).

Copyright Law of the People's Republic of China (2010 amended).

Copyright Ordinance of Hong Kong (Cap. 528) (2009 amended).

Intellectual Property Code of France (2003 amended).

Law for the Protection of Copyright and Neighboring Rights in Italy (2010 amended).

United States Copyright Act, 17 U.S.C.

\section{Jurisprudence}

A \&M Records Ltd. v. Video Collection International Ltd. [1995] EMLR 251.

Beggars Banquet v Carlton Television, [1993] EMLR 349.

Campbell v. Acuff-Rose Music, 510 U.S. 569 (1994).

Century Communications v Mayfair Entertainment, [1993] EMLR 335.

Chan Nai Ming v HKSAR, [2007] 3 HKC 255.

Commissioner of Customs and Excise v. Golden Science Technology Ltd, [1999] 4 HKC 169.

HKSAR v Chan Nai Ming [2005] 4 HKLRD 142.

HKSAR v Elegant Technology Ltd, [2004] 3 HKC 37.

HKSAR v Ho Hon Chung Danel \& ORS, [2004] 3 HKC 304.

HKSAR v Mega Laser Products (HK) Ltd \& ORS, [1999] 3 HKC 161.

HKSAR v Re Affluence Pictures Ltd. (2008). HKCU, 1807.

HKSAR v SZE Chak Ming \& ANOR, [2006] HKCU 724.

Leibovitz v. Paramount Pictures Corp., 137 F.3d 109 (2d Cir. 1998).

Mattel Inc., v. Walking Mountain Productions, 353 F.3d 792 (9th Cir. 2003).

Suntrust v. Houghton Mifflin Co., 268 F.3d 1257 (11th Cir. 2001). 


\section{Books}

Chan, J. M., et al. (2010). Policies for the sustainable development of the Hong Kong film industry. Hong Kong: Hong Kong Institute of Asia-Pacific Studies.

Christakis, N. A., \& Fowler, J. H. (2009). Connected: The surprising power of our social networks and how they shape our lives. New York: Little \& Brown.

Cooter, R., \& Ulen, T. (2010). Law and economics (6th ed.). Harlow: Pearson.

Drassinower, A. (2015). What's wrong with copying? Harvard University Press.

Drew, J. (2013). A social history of contemporary democratic media. London: Routledge.

Fisher, W. (2004). Promise to keep: Technology, law and the future of entertainment. Stanford: Stanford University Press.

Kamina, P. (2016). Film copyright in the European Union. Cambridge: Cambridge University Press.

Pang, L. (2006). Cultural control and globalization in Asia: Copyright, piracy, and cinema. London: Routledge.

Thorburn, D., \& Jenkins, H. (2004). Rethinking media change: The aesthetics of transition. Cambridge, MA: The MIT Press.

Torremans, P. (Ed.). (2014). Research handbook on the cross-border enforcement of intellectual property. Cheltenham: Edward Elgar Publication.

Weisenhaus, D. (2004). Hong Kong media law: A guide for journalists and media professionals. Hong Kong: Hong Kong University Press.

Zhang, Y. (2012). A companion to Chinese cinema. Malden: Wiley-Blackwell.

\section{Journal Articles}

Chan, C. S. C. (2010). Housekeeper of Hong Kong cinema: The role of producer in the system of Hong Kong film industry. Wide Screen, 2, 1.

Desser, D. (2009). Triads and changing times: The National Allegory of Hong Kong cinema, 1996-2000. QRFV, 26, 179.

Dougherty, F. J. (2001). Not a spike Lee joint-issues in the authorship of motion pictures under the US copyright law. 49 UCLA Law Review, 225.

Liu, J. P. (2006). Copyright and breathing space. 30 COLUM. J.L. \& Arts, 429.

Mo, J. Y. C. (2017). The Copyright (Amendment) Bill 2014 in Hong Kong: A blessing or a curse? STAT. $L R, 38,211$.

Szeto, M. M., \& Chen, Y.-c. (2013). To work or not to work: The dilemma of Hong Kong film labor in the age of mainlandization. 55 JUMP CUT 1.

Yu, P. K. (2010). Digital copyright reform and legal transplants in Hong Kong. 48 U. LOUISVILLE L. Review 693.

Yu, P. K. (2016). The quest for a user-friendly copyright regime in Hong Kong. 32 AM. U. INT'L L. REV. 284.

\section{Official Reports}

HKTDC Research. (2018, March 15), Film \& Entertainment Industry in Hong Kong. Available at http://hong-kong-economy-research.hktdc.com/business-news/article/Hong-Kong-IndustryProfiles/Film-Entertainment-Industry-in-Hong-Kong/hkip/en/1/1X000000/1X0018PN.htm 
Hong Kong's Piracy Landscape. (2018). Carnegie Mellon University "the dual impact of movie piracy on box-office revenue: Cannibalization and promotion", Feb. 2017. Available at http://hkisa.film/contenthtml/Information_Material/2018/ Hong-Kong-Piracy-Landscape-2018_v4.pdf

Legislative Council Brief of Copyright (Amendment) Bill 2014 of Hong Kong.

Legislative Council Brief on Facilitating Cinema Development, Lc Paper No. Cb(4)801/16-17(05). Available at https://www.legco.gov.hk/yr16-17/english/panels/itb/papers/itb20170410cb4801-5-e.pdf

Legislative Council of the Hong Kong Special Administrative Region of the People's Republic of China, Challenges of the Film Industry in Hong Kong. Available at https://www.legco.gov.hk/ research-publications/english/essentials-1516ise13-challenges-of-the-film-industry-in-hongkong.htm

Legislative Council Panel on Information Technology and Broadcasting, Film Development Fund Review, Lc Paper No. CB(4)187/17-18(02). Available at https://www.legco.gov.hk/yr17-18/ english/panels/itb/papers/itb20171113cb4-187-2-e.pdf

\section{Newspapers \& Websites}

Chow, V. (2017). Handover hangover: Hong Kong's film industry faces an uncertain future, VARIETY, May 17, 2017. Available at http://variety.com/2017/biz/news/ wong-kar-wai-1202430867-1202430867

Create HK. About us. Available at https://www.createhk.gov.hk/en/about.htm\#

Create HK. Services. Available at https://www.createhk.gov.hk/en/service_film.htm

$\mathrm{Ge}$, Celine. It's fade out for Hong Kong's film industry as china moves into the spotlight, South China Morning Post, Jul. 28, 2017. Available at http://www.scmp.com/business/ article/2104540/its-fade-out-hong-kongs-film-industry-china-moves-spotlight

Hong Kong Arts Development Council, Cultural Exchange. Available at http://www.hkadc.org. $\mathrm{hk} / \mathrm{p}=435$ \&lang=en

Hong Kong Film Development Council. Home page. Available at http://www.fdc.gov.hk/en/home/ index.htm

Hong Kong Film Development Council. Services. Available at http://www.fdc.gov.hk/en/services/ services $2 . h t m$

Hong Kong Film Industry Furious at YouTube 'Piracy', Asia One, Apr. 25, 2012. Available at http://www.asiaone.com/News/Latest\%2BNews/Showbiz/Story/A1Story20120425-342040. html

Hong Kong Free Press. A glimmer of hope for young filmmakers in Hong Kong's fading industry. Available at https://www.hongkongfp.com/2017/11/05/ glimmer-hope-young-filmmakers-hong-kongs-fading-industry

Hong Kong International Film \& TV Market (FILMART). Fair report. Available at http://m.hktdc. com/resources/fair/1819/hkfilmart/s//4129/1527476733800_Fair-Report-FILMART201823May-Eng.pdf

Hong Kong International Film Festival Society, About us. Available at http://www.hkiff.org.hk/ society/\#/AboutUs/historyCulture

Kei, S., et al. (2001). A brief historical tour of the Hong Kong martial arts film, BRIGHT LighTs, Jan. 1. Available at https://brightlightsfilm.com/wp-content/cache/all/brief-historical-tourhong-kong-martial-arts-film/\#.W3rD4egzY2x

Lau, S. (2016). Five reasons the Hong Kong copyright bill failed. South China Morning Post, Mar. 4, 2016. Available at https://www.scmp.com/news/hong-kong/politics/article/1920569/ five-reasons-hong-kong-copyright-bill-failed 
Mainland offers Hong Kong's film industry a chance for a brighter future. SoutH CHINA Morning Post, Mar. 18, 2018. Available at https://www.scmp.com/comment/insight-opinion/ article/2137677/mainland-offers-hong-kongs-film-industry-chance-brighter

Shen, A. Online piracy clampdown in Hong Kong deprives errant websites of HK\$6.5 million in monthly ad revenue, South China Morning Post, Mar. 22, 2018. Available at https://www.scmp.com/news/hong-kong/law-crime/article/2138287/ online-piracy-clampdown-hong-kong-deprives-errant-websites

Tito, G. (2011). Valve's Gabe Newell says piracy is a service problem, THE ESCAPIST, Nov. 28, 2011. Available at http://www.escapistmagazine.com/news/ view/114391-Valves-Gabe-Newell-Says-Piracy-Is-a-Service-Problem

Open Access This chapter is licensed under the terms of the Creative Commons Attribution 4.0 International License (http://creativecommons.org/licenses/by/4.0/), which permits use, sharing, adaptation, distribution and reproduction in any medium or format, as long as you give appropriate credit to the original author(s) and the source, provide a link to the Creative Commons license and indicate if changes were made.

The images or other third party material in this chapter are included in the chapter's Creative Commons license, unless indicated otherwise in a credit line to the material. If material is not included in the chapter's Creative Commons license and your intended use is not permitted by statutory regulation or exceeds the permitted use, you will need to obtain permission directly from the copyright holder. 